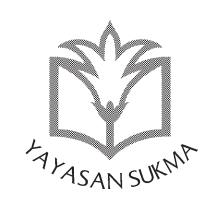

SUKMA: JURNAL PENDIDIKAN

ISSN: 2548-5105 (p), 2597-9590 (e)

Volume 2 Issue 2, Jul-Dec 2018, pp. 247-260

https://doi.org/10.32533/02205.2018

www.jurnalsukma.org

\title{
BUDAYA MENGHAFAL ALQURAN Motivasi dan Pengaruhnya Terhadap Religiusitas
}

\section{Nurul Huda}

Universitas Islam Negeri Sunan Kalijaga Yogyakarta, Indonesia email: alhuda0801@gmail.com

\section{Abstrak}

Alquran pada masa awal turunnya banyak dihafalkan oleh para sahabat. Mereka menghafal dengan motivasi utama menjaga kemurnian dan kelanggengan Alquran. Karena jika Alquran tidak dihafal, dengan sendirinya Alquran akan hilang. Seiring berjalannya waktu, semakin banyak umat Islam yang menghafal Alquran. Tentu tujuan utama bukanlah untuk menjaga kelanggengan Alquran, karena sudah banyak teknologi canggih untuk menyimpan Alquran. Motivasi mereka kini bermacam-macam. Tulisan ini membahas motivasi-motivasi para penghafal Alquran masa kini. 
Sekaligus menyelidiki pengaruh hafalan Alquran terhadap religiusitas mereka. Data lingkup kecil menemukan bahwa hafalan mereka tidaklah berpengaruh secara siginifakan terhadap religiusitas mereka.

Keywords: hafalan Alquran, motivasi menghafal, religiusitas.

\section{A. Pendahuluan}

Disiplin kajian Ulum Al-Quran telah membahas proses perekaman wahyu atau Jam' Al-Quran. Dalam proses perekaman wahyu, Alquran dijaga dengan dua metode; metode menghafal dan metode menulis (Subhi As-Shalih 2001, 40). Masing-masing metode memiliki cara tersendiri dalam menjaga kemurnian dan kelanggengan wahyu. Jam' Al-Quran dengan metode menghafal berarti menjaga Alquran dari kepunahan dengan cara mengingat dan menghafal Alquran dalam hati dan pikiran. Perekaman wahyu dengan metode menulis berarti menjaga Alquran dengan cara mengubah keseluruhan ayat-ayat Alquran menjadi tulisan.

Kedua metode menghafal dan menulis ini masih tetap berlangsung hingga saat ini. Alquran masih tetap dicetak bahkan semakin banyak dengan teknologi yang semakin maju. Alquran juga masih tetap dihafal oleh banyak kalangan muslim di seluruh dunia. Pada masa awal turunnya wahyu, Alquran banyak dihafal dengan tujuan untuk memelihara Alquran dari kepunahan dan memang karena pada masa itu adalah fase oral (lisan) dalam kajian Ulum Al-Quran. Alquran dijaga dan dipelihara dengan cara dihafal, masih sedikit para sahabat yang menulis wahyu, karena pada masa itu - dalam kajian Ulum Al-Quran - masyarakat Arab pada waktu itu belum banyak yang menguasai baca tulis (Nasr Hamid Abu Zaid 2005, 14).

Dari pemaparan di atas, jelas bahwa para Sahabat - pada masa turunnya wahyu - menghafal Alquran dengan motivasi utama menjaga Alquran dari kepunahan. Adapun masa sekarang, Alquran telah banyak diabadikan dalam berbagai macam bentuk dengan berbagai macam teknologi, baik dalam bentuk tulisan 
maupun suara (kaset, CD, VCD dan lain sebagainya). Sehingga pada masa sekarang, jika motivasi para penghafal Alquran adalah menjaga Alquran dari kepunahan, kiranya sudah tidak relevan. Sebagai pelaku penghafal Alquran (masih dalam proses), penulis pernah beberapa kali bertukar pikiran dengan para penghafal lain di sebuah pondok tahfidz sederhana (tempat penulis menyetorkan hafalan dan muroja'ah) di daerah Purworejo, Jawa Tengah.

Data lingkup kecil yang penulis temukan di Purworejo adalah sebagian besar para penghafal Alquran berasal dari keluarga menengah ke bawah. Mereka memilih menjadi penghafal Alquran karena mereka tidak mampu melanjutkan pendidikan formal pada tingkat selanjutnya. Mereka rata-rata hanya lulusan MTs atau yang sederajat. Sebagian yang lain berasal dari keluarga mampu, tetapi keluarga mereka adalah keluarga penghafal Alquran. Faiz misalnya, ayah dan ibunya masing-masing adalah seorang hafidz Alquran. Ayahnya memiliki pondok pesantren khusus penghafal Alquran yang santrinya lumayan banyak. Adapun Faiz hanya mengenyam pendidikan formal sampai lulus MTs.

Seorang teman lain (seorang lulusan SMA) bercerita, ia bercita-cita dapat menghafal Alquran 30 juz supaya bisa mendapatkan beasiswa untuk melanjutkan belajar (kuliah) di Mesir. Beberapa lembaga pendidikan bahkan mensyaratkan, untuk bisa masuk pada lembaga tersebut harus hafal beberapa juz Alquran. Selain itu juga beberapa lembaga pendidikan tinggi memberikan beasiswa kepada para mahasiswanya yang hafal beberapa atau seluruh ayat dalam Alquran. Dari sini tampak bahwa motivasi menghafal Alquran adalah untuk mendapatkan beasiswa.

Beberapa penghafal lain mengungkapkan bahwa cita-cita mereka menghafal Alquran adalah untuk mengangkat derajat keluarga, sebagaimana yang disabdakan oleh Nabi Muhammad dalam beberapa hadits. Dalam beberapa hadits diungkapkan bahwa seseorang yang hafal Alquran dan senantiasa menjaga 
hafalannya akan mendapatkan kemuliaan berupa memberikan syafaat (pertolongan) kepada sepuluh anggota keluarganya pada hari kiamat. Dengan berpegangan pada hadits ini, seorang penghafal Alquran akan mendapatkan kemuliaan berupa penghormatan dari masyarakat. Ini berarti ada keuntungan sosial yang didapatkan oleh penghafal Alquran.

Fenomena menarik yang penulis temukan juga, mayoritas para penghafal Alquran ini menjadikan predikat hafidz Alquran sebagai predikat tertinggi. Predikat hafidz Alquran adalah tujuan utama mereka. Mereka sudah puas dengan mengkhatamkan hafalan Alquran 30 juz dengan 'lanyah'. Padahal jika ditanya tentang pemahaman keislaman terutama tentang masalahmasalah yang ada dalam Alquran, mereka belum tentu bisa menjawabnya. Mereka hafal dengan 'lanyah' keseluruhan ayat dalam Alquran disebabkan kebiasaan 'muroja'ah' hafalan secara terus menerus (istiqomah). Mereka para hafidz Alquran memiliki 'kewajiban' untuk 'nderes' minimal beberapa juz Alquran setiap harinya. Sehingga mereka benar-benar harus meluangkan waktu yang cukup untuk hal tersebut.

Adapun spiritualitas para penghafal Alquran yang penulis jumpai dalam lingkup kecil, mereka memiliki spiritualitas yang tidak jauh berbeda dari orang-orang yang tidak menghafalkan Alquran. Mereka yang menghafalkan Alquran, sebagian masih melakukan beberapa perbuatan yang oleh agama diperintahkan untuk menjauhi. Sebagian mereka masih belum bisa menjaga kebersihan, lingkungan pondok terlihat begitu kumuh, membuang sampah sembarangan. Tidak menundukkan pandangan pada lawan jenis, bahkan menonton gambar dan video yang berbau blue film. Dari pemaparan ini, penulis ingin mengetahui motivasi apa yang mendorong para penghafal Alquran memilih untuk menapaki jalan menjadi hafidz Alquran, dan adakah hubungan antara religiusitas dengan menghafal Alquran.

\section{B. Habitus, Selera, Kapital, dan Arena}

Habitus bagi Bourdieu sebagaimana yang dikutip oleh 
Haryatmoko dalam bukunya, Membongkar Rezim Kepastian (Haryatmoko 2016, 41) adalah suatu jenis sistem disposisi: kondisi yang terkait dengan syarat-syarat keberadaan suatu kelas menghasilkan suatu habitus. Habitus merupakan hasil keterampilan yang menjadi tindakan praktis - tidak harus selalu disadari yang kemudian diterjemahkan menjadi suatu kemampuan yang kelihatannya alamiah dan berkembang dalam lingkungan sosial tertentu.

Habitus menurut Bourdieu adalah kebiasaan masyarakat yang melekat pada diri seseorang dalam bentuk disposisi abadi, atau kapasitas terlatih dan kecenderungan terstruktur untuk berpikir, merasa dan bertindak dengan cara determinan, yang kemudian membimbing mereka. Jadi Habitus tumbuh dalam masyarakat secara alami melalui proses sosial yang sangat panjang, terinternalisasi dan terakulturasi dalam diri masyarakat menjadi kebiasaan yang terstruktur secara sendirinya. Habitus dibuat melalui proses sosial, bukan individu yang mengarah ke pola yang abadi dan ditransfer dari satu konteks ke konteks lainnya, tetapi yang juga bergeser dalam kaitannya dengan konteks tertentu dan dari waktu ke waktu. Habitus tidak tetap atau permanen, dan dapat berubah di bawah situasi yang tak terduga atau selama periode sejarah panjang. Bourdieu dalam bukunya juga mengatakan bahwa Habitus bukanlah hasil dari kehendak bebas, atau ditentukan oleh struktur, tapi diciptakan oleh semacam interaksi antar waktu. Dalam pengertian ini habitus dibuat dan direproduksi secara tidak sadar.

Aplikasi dari konsep Habitus yang dikemukakan oleh Pierre Bourdieu bisa kita lihat dengan beberapa contoh kasus dimasyarakat. Misalnya dalam budaya masyarakat Indonesia khususnya masyarakat Jawa. Kita mengenal dengan budaya patrimonial, dimana ketundukan seorang rakyat pada raja (penguasa). Tabu bagi masyarakat Jawa untuk menentang segala titah raja, kebiasaan ini sudah melekat dalam tradisi masyarakat Jawa. Dimana pemimpin (raja, penguasa, pemerintah) meruapakan titisan Tuhan dimuka bumi. Budaya patrimonial ini bisa dilihat pada masa pemerintahan orde baru dengan sistem pemer- 


\section{Nurul Huda}

intahan yang otoriter. Semua struktur pemerintahan terpusat dibawah tampuk komando Soeharto, segala titah Soeharto harus dilaksanakan. Budaya "bapakisme" atau asal bapak senang sudah terinternalisasi selama 32 tahun masa pemerintahan Soeharto, terutama dalam tubuh birokrasi di Indonesia, yang mungkin dewasa ini kita masih bisa merasakannya.

Selain itu, contoh lainnya adalah budaya "Patriarki" atau kedudukan perempuan dalam struktur sosial masyarakat. Dalam adat budaya timur, khususnya Indonesia, perempuan selalu menjadi subordinat dari laki-laki dalam berbagai hal. Posisi subordinat dalam masyarakat ini terbentuk secara alami dan terinternalisasi dalam waktu yang lama. Sehingga sudah menjadi asumsi umum bahwa perempuan berada dibawah laki-laki. Seaktif apapun peranan perempuan diluar baik dalam berbagai ranah seperti politik, bisnis, hukum, maupun ekonomi, saat kembali ke rumahnya tetap kedudukan perempuan menjadi istri rumah tangga, laki-laki yang menjadi pemimpin keluarga. Ini menjadi kebiasaan dalam kultur masyarakat Indonesia, dimana tabu bagi perempuan untuk melakukan tugas laki-laki, termasuk dalam terjun dalam arena politik.

Kebanyakan orang menerima selera sebagai sesuatu yang personal, individual, privat, subyektif: sepenuhnya pilihan pribadi. Selera adalah preferensi yang semata-mata didasari oleh kepentingan pribadi. Bourdieu memiliki pendapat berbeda. Menurut Bourdieu, selera bukanlah sesuatu yang alamiah. Ia bukan "pilihan" bebas. Ia bukan "hak" prerogatif individu. Selera, urai Bourdieu, adalah produk konstruksi sosial yang dibentuk, terutama, melalui pendidikan dan pengasuhan. Selera, lebih jauh, juga berfungsi sebagai penanda status sosial. Buku Distinction: A Social Critique of the Judgement of Taste (1979), yang ditulis Bourdieu, menjelaskan bagaimana selera dibentuk secara sosial dan sekaligus menjadi "pembeda" status sosial.

Berbasis data survei, Bourdieu sampai pada kesimpulan mengejutkan. Menurutnya, selera dibentuk nyaris di luar kontrol individu, bergerak di bawah level kesadaran dan bahasa melalui 
relasi antara habitus, kapital, dan field. Habitus adalah seperangkat persepsi, pikiran dan tindakan yang diperoleh melalui $a$ way of being, a habitual state, yang ia sebut "disposition" (1977, 214). Disposisi menjadi semacam kecenderungan, tendensi, seseorang. Habitus terutama dibentuk melalui proses pendidikan dan pengasuhan. Ia juga dipengaruhi asal usul keluarga dan kelas sosial. Habitus, di satu sisi, urai Bourdieu, merupakan struktur pembentuk tindakan, yang menentukan pilihan selera. Di sisi lain, habitus juga merupakan struktur yang dibentuk oleh pilihan selera seseorang. Dengan kata lain, perbedaan habitus membedakan selera dan sekaligus menguatkan selera.

Selain habitus, selera juga dipengaruhi jumlah dan komposisi kapital. Kapital, berbeda dengan Karl Marx, bagi Bourdieu tidak hanya merujuk semata pada kapital ekonomi (modal atau uang). Bagi Bourdieu, kapital bisa berupa kapital budaya (pendidikan, kecerdasan, cara berbicara, gaya berpakaian, penampilan fisik), kapital sosial (jaringan, teman, kolega, klub) dan kapital simbolik (lukisan, gelar, titel, medali, penghargaan). Selera, ujar Bourdieu, dipengaruhi oleh seberapa besar kapital ekonomi, budaya, sosial dan simbolik yang dimiliki seseorang, dan bagaimana komposisi keempat kapital tersebut. Seseorang yang hanya memiliki sedikit kapital ekonomi, kapital budaya, kapital sosial dan kapital simbolik (kelas pekerja), misalnya, memiliki selera yang berbeda dengan seseorang yang memiliki lebih banyak kapital dengan komposisi yang lengkap (kelas pemilik modal).

Selera juga dipengaruhi oleh field atau arena sosial. Arena sosial adalah latar atau setting dimana posisi sosial seseorang berada. Arena sosial tercipta melalui proses interaksi antara habitus dan kapital yang dimiliki individu. Mengikuti Max Weber, Bourdieu menolak pandangan Marxisme tradisional yang melihat masyarakat secara dikotomis hirarkis, berdasarkan status kelas (berbasis ekonomi kepemilikan): kelas borjuis versus proletar. Bourdieu lebih memilih memakai istilah class fraction, untuk menjelaskan bagaimana kelas-kelas di dalam masyarakat, bahkan dalam satu kelas sosial yang sama, saling bermanuver dalam arena sosial untuk saling menguasai. Arena sosial yang berbeda 
menciptakan pilihan selera yang berbeda pula.

Mengikuti Bourdieu, berlawanan dengan pandangan kebanyakan orang, selera bukanlah sesuatu yang dipilih secara "bebas." Ia bukan sesuatu yang personal, individual, privat, subyektif. Selera terhadap segala yang berbau Korea, selera terhadap film India, selera terhadap makanan organik, selera terhadap film indie, selera terhadap sepakbola, golf atau memancing, dan selera terhadap apapun, simpul Bourdieu, selalu merupakan produk interaksi antara habitus, kapital dan arena sosial tertentu.

\section{Motivasi Menghafal Alquran}

Motivasi yang dimiliki oleh para penghafal Alquran cukup beragam. Beberapa penghafal Alquran memilih menjadi penghafal Alquran karena mereka berasal dari keluarga penghafal Alquran. Faiz misalnya, salah seorang teman penulis ketika 'ngaji' di sebuah pondok pesantren tahfidz di Purworejo, ayah dan ibunya adalah seorang hafidz Alquran. Dia sejak kecil sudah terbiasa mendengar bacaan Alquran baik itu dari ayahnya, para santrinya maupun dari kaset murottal yang diperdengarkan. Faiz semenjak kecil sudah terbiasa dengan lingkungan para penghafal Alquran, sehingga motivasi ini tumbuh dengan sendirinya, ia ingin mengimbangi lingkungannya. Merujuk pada teori yang dikemukakan oleh Pierre Bourdieu, motivasi Faiz ini termasuk dalam ranah kajian habitus. Faiz memilih menjadi penghafal Alquran karena sejak kecil dia sudah terbawa oleh arus lingkungan keluarga sebagai penghafal Alquran. Sehingga selera atau motivasi untuk menghafal Alquran yang dimiliki oleh Faiz ini cukup tinggi.

Selera untuk menghafalkan Alquran yang dimiliki Faiz ini, bukan merupakan pilihan yang muncul tanpa sebab. Motivasi dan selera yang dimiliki Faiz ini lahir dari pola didikan dan asuhan yang ia dapatkan semenjak kecil. Habitus yang dialami oleh Faiz ini, merupakan salah satu gambaran yang ada pada para penghafal Alquran. Mereka menjadi penghafal Alquran karena didorong oleh selera yang dihasilkan dari habitus, kebiasaan 
dan hasil didikan dari keluarga sejak kecil. Beberapa penghafal Alquran memang berasal dari keluarga pesantren yang notabene menspesialisasikan hafalan Alquran.

Selain itu, kebanyakan penghafal Alquran yang penulis temui, mereka memiliki persepsi bahwa seorang hafidz Alquran itu akan mendapatkan kedudukan dan kemuliaan di masyarakat. Fenomena yang terjadi dalam masyarakat muslim di Purworejo adalah mereka yang hafidz Alquran akan mendapatkan prioritas dalam berbagai ritual maupun acara keagamaan. Seorang hafidz Alquran diprioritaskan untuk menjadi imam tetap beberapa masjid di Purworejo. Seorang hafidz Alquran akan diprioritaskan untuk menjadi imam yasinan, tahlilan, maupun membaca doa. Dengan demikian, seorang hafidz Alquran akan mendapatkan keuntungan sosial bahkan keuntungan ekonomi, dimana berdasarkan teori yang dikemukakan oleh Pierre Bourdieu, keuntungan sosial diperoleh karena mereka para penghafal Alquran memiliki kapital (modal) budaya dan kapital simbolik. Kedudukan sosial yang menjanjikan ini menjadi motivasi tersendiri bagi para penghafal Alquran.

Beberapa kelompok Islamis bahkan sangat mengidolakan tokoh yang memiliki kelebihan berupa hafidz Alquran ini. Kasus yang sedang hangat sekarang ini misalnya, Tuan Guru Bajang Zainul Majdi, seorang gubernur NTB, yang dahulu menjadi tim pemenangan Prabowo Subianto - yang lebih banyak didukung oleh kelompok Islamis - sekarang heboh dengan pernyataan sikap dukungannya terhadap Jokowi - yang kebanyakan pendukungnya adalah kelompok nasionalis. Jika merujuk pada teori yang dikemukakan oleh Pierre Bourdieu, tentunya TGB ini akan banyak mendongkrak perolehan suara jika TGB menjadi cawapres Jokowi pada 2019 nanti.

Fenomena lain yang penulis temui adalah kebanyakan kyai pemilik pondok pesantren tahfidz di Purworejo tidak memiliki usaha bidang perekonomian. Mereka hanya mengandalkan syahriyah (iuran bulanan) dari para santri. Donasi juga datang dari banyak donatur. Sehingga, mereka para kyai pengasuh pondok 
pesantren tahfidz bisa membangun asrama yang jauh dari layak untuk para santrinya, bahkan untuk tempat tinggalnya sendiri. Dengan demikian, selain keuntungan sosial, para penghafal Alquran juga mendapatkan keuntungan ekonomi. Atau dengan kata lain, kapital budaya dan kapital simbolik yang diperoleh oleh para penghafal Alquran akan berdampak pada keuntungan ekonomi.

Fakta yang penulis temukan di Purworejo, mayoritas para penghafal Alquran ini berasal dari kalangan keluarga menengah ke bawah yang berpendidikan formal rendah. Beberapa penelitian lain juga menemukan data yang sama. Misalnya penelitian yang dilakukan oleh Mutammam di daerah Brebes, mengungkapkan bahwa kemampuan ekonomi para penghafal Alquran di Brebes juga beragam. Yang pertama adalah mereka yang kaya dan yang kedua mereka yang miskin dan sedang-sedang saja. Kelompok pertama jumlahnya tidak banyak, yakni mereka yang memiliki pesantren atau dari keluarga dekat pemilik pesantren. Bagi kelompok ini, kekayaan berasal dari keluarga dan dari posisi sosialnya sebagai pemilik pesantren. Seorang yang hafal Alquran yang memiliki pesantren, tentu lebih sejahtera karena hadiah-hadiah yang diterimanya dari orangtua para santrinya dan tamu-tamu lain yang datang meminta jasanya. Lebih dari itu, para penghafal Alquran yang memiliki pesantren juga umumnya lebih sering mendapat undangan sima'an di luar daerah.

Sementara para penghafal Al-quran Benda yang tidak memiliki pesantren pada umumnya kemampuan ekonominya biasa-biasa saja. Sumber-sumber pendapatan ekonomi mereka peroleh melalui berdagang barang-barang keperluan santri, bertani, mengajar di sekolah di lingkungan pesantren, dan 'amplop' dari undangan-undangan sima'an Alquran di luar daerah. Namun khusus yang terakhir, bersifat tidak menentu baik dalam jumlah maupun dalam frekuensi undangan yang mereka terima setiap bulannya. Bagi penghafal Alquran yang hanya bisa mengajar hafalan Alquran dan tidak memiliki sumber-sumber pendapatan ekonomi yang diperoleh dari keluarga, maka kemampuan ekonomi mereka sangat terbatas. 
Mereka memilih untuk menjadi penghafal Alquran karena orang tua mereka tidak mampu membiayai sekolah ke jenjang yang lebih tinggi. Orang tua mereka, berharap dengan anaknya menjadi hafidz Alquran, akan mengangkat derajat keluarga. Sehingga jelas, konsep Bourdieu bahwa kapital budaya dan simbolik ini adalah tujuan mereka.

Adanya dominasi kapital budaya dalam hal ini juga tampak pada banyaknya lembaga yang menyediakan beasiswa pendidikan untuk para penghafal Alquran. Bahkan beberapa perguruan tinggi dan lembaga pendidikan lainnya mensyaratkan peserta didik hafal beberapa juz Alquran atau bahkan seluruh Alquran.

\section{Religiusitas Para Penghafal Alquran}

Berbicara masalah religisusitas, akan sedikit ada hubungannya dengan spiritualitas. Religiusitas lebih cenderung kepada pengamalan ritual-ritual keagamaan, adapaun spiritualitas lebih cenderung kepada pengamalan norma ketuhanan. Walaupun berbeda pengertian, tetapi spiritualitas tidak terlepas dari religiusitas, termasuk juga pemahaman agama. Pemahaman agama para penghafal Alquran bervariasi, bergantung pada proses belajar yang pernah mereka jalani. Namun nampaknya, secara umum, pemahaman agama mereka terutama para penghaf Alquran perempuan, terbatas pada hal-hal yang berkait dengan Alquran.

Penjelasannya adalah, karena sebagian besar dari para penghafal Alquran adalah perempuan yang datang dari keluarga biasa yang tidak mampu membiayai pendidikan tinggi anakanaknya. Lagi pula, biasanya mereka belajar menjadi penghafal Alquran dengan menghafal di pesantren-pesantren di luar pun hanya berproses melalui menghafal Alquran. Hampir tidak ada penghafal Alquran perempuan yang menghafal sambil belajar ilmu-ilmu agama di luar yang berkaitan dengan ilmu Alquran.

Berbeda dari para penghafal Alquran perempuan, kalangan penghafal Alquran laki-laki secara umum lebih berdaya dibanding temannya yang perempuan dalam hal pemahaman agama. 


\section{Nurul Huda}

Meski dari segi pendidikan mereka tidak berbeda jauh dari teman-teman mereka yang perempuan, para penghafal Alquran laki-laki umumnya juga belajar kitab kuning pada saat mereka menjalani proses mesantren menghafal Alquran. Salah satu sebabnya adalah, waktu yang mereka miliki lebih luas lantaran mereka tidak terganggu oleh masa-masa menstruasi.

Pemahaman keagamaan pada diri para penghafal Alquran nantinya berkait dengan peran dan status sosial yang mereka mainkan di tengah masyarakat. Jika beberapa penghafal Alquran laki-laki adalah juga kiai yang mengajar ilmu-ilmu agama atau menjadi guru di sekolah, adalah karena mereka memiliki pemahaman agama lebih. Pemahaman tersebut diperoleh karena semasa belajar mereka memiliki waktu yang relatif lebih longgar dibanding para penghafal Alquran perempuan untuk mengaji kitab-kitab agama.

Beberapa penghafal Alquran yang penulis temui, mereka tidak begitu memahami ilmu tata bahasa Arab (Nahwu Sharaf dan sebagainya). Mereka menghafalkan Alquran sesuai dengan harapan mereka saja. Mereka akan merasa sangat puas jika sudah bisa menghafalkan secara 'lanyah' 30 juz Alquran. Mereka tidak begitu mempedulikan apa maksud yang terkandung dari ayat-ayat yang dihafalkannya. Beberapa para pelaku penghafal Alquran yang penulis temui, hafalan mereka tidak begitu berpengaruh secara signifikan terhadap religiusitas mereka. Karena harapan mereka yang terpenting adalah hafal dengan 'lanyah' (lancar).

\section{E. Penutup}

Tadisi menghafal Alquran dalam masyarakat memiliki ragam latar belakang motivasi pelakunya. Berdasar hasil uraian di atas, para penghafal Alquran ini ada yang memilih menjadi penghafal Alquran karena memang cita-cita hidup pelaku, kemudian ada juga karena keuntungan sosial dan ekonomi yang akan mereka peroleh, kebutuhan oleh masyarakat, serta dukungan dan fasilitasi pihak yang memiliki kekuasaan. Cita-cita hidup 
menjadi penghafal Alquran di kalangan masyarakat berkembang karena keyakinan mereka bahwa predikat yang paling tinggi untuk mencapai keridhaan Tuhan adalah Alquran. Melalui basis ideologi -kecintaan kepada Alquran dan kepada orang-orang yang hafal Alquran ini, kelangsungan tradisi menghafal Alquran terus berlanjut hingga sekarang.

Institusi keluarga dan lingkaran guru murid merupakan agen-agen yang bekerja aktif dalam proses pewarisan tradisi menghafal Alquran. Hal ini memperkuat teori habitus dan kapitalnya Bourdieu bahwa tindakan individu berasal dari kebiasaan atau pengalaman individu pada masa sebelumnya (masa kecil) dan juga kebiasaan-kebiasaan lain. Ketika tradisi menghafal Alquran telah melahirkan komunitas penghafal Alquran, maka pengorganisasian para penghafal Alquran ke dalam satu wadah berpengaruh positif terhadap eksistensi mereka. Melalui pengorganisasian, para penghafal Alquran memiliki kesempatan mengembangkan jaringan bagi pemberdayaan dan sebagai akibatnya peluang mendapatkan keuntungan sosial dan ekonomi pun menjadi besar.

Adapun pengaruh menghafal Alquran terhadap religiusitas para penghafalnya tidaklah terlalu signifikan. Para penghafal Alquran masih mempertahankan beberapa karakter atau sifat yang didapatkan dari lingkungan keluarga di mana ia berasal. 


\section{DAFTAR PUSTAKA}

Abdurrahman, Dudung. 2014. Komunitas-Multikultural dalam Sejarah Islam Periode Klasik. Yogyakarta: Penerbit Ombak.

Abu Zaid, Nasr Hamid. 2005. Tekstualitas Al-Quran, trans. Khoiron Nahdliyyin. Yogyakarta: LKiS Pelangi Aksara.

Athaillah, H.A. 2010. Sejarah al-Quran. Yogyakarta: Pustaka Pelajar. Haryatmoko. 2016. Membongkar Rezim Kepastian. Yogyakarta: Kanisius.

Hasan, Noorhaidi. 2018. Literatur Keislaman Generasi Milenial. Yogyakarta: UIN Sunan Kalijaga.

Pals, Daniel L. 2012. Seven Theories of Religion, trans. Syukri. Yogyakarta: Divapress.

As-Shalih, Subhi. 2001. Membahas Ilmu-ilmu Al-Quran. Jakarta: Pustaka Firdaus.

Tibi, Bassam. 1999. Islam, Kebudayaan, dan Perubahan Sosial, trans. Misbah \& Zainul. Yogyakarta: Tiara Wacana Yogyakarta. 